\title{
AIRWAY VISUALIZATION: EYES SEE WHAT MIND KNOWS
}

\author{
Massimiliano Sorbello ${ }^{1}$, Giulio Frova ${ }^{2}$ and Ivana Zdravković $^{3}$ \\ ${ }^{1}$ Anesthesia and Intensive Care, AOU Policlinico Vittorio Emanuele, Catania; ${ }^{2}$ Anesthesia and Intensive Care, \\ University of Milan, Italy; ${ }^{3}$ Anesthesia and Intensive Care, Zvezdara Clinical Center, Belgrade, Serbia
}

\begin{abstract}
SUMMARY - Airway management is basic for anesthesia practice, and sometimes it can represent a really dramatic scenario for both the patient and the physicians. Laryngoscopy has been the gold standard of airway visualization for more than 60 years, showing its limitations and failure rates with time. New technology has made available an opportunity to move the physician's eye inside patient airways thanks to video laryngoscopy and video assisted airway management technique. Undoubtedly, we have entered a new era of high resolution airway visualization and different approach in airway instrumentation. Nevertheless, each new technology needs time to be tested and considered reliable, and pitfalls and limitations may come out with careful and long lasting analysis, so it is probably not the right time yet to promote video assisted approach as a new gold standard for airway visualization, despite the fact that it certainly offers some new prospects. In any case, whatever the visualization approach, no patient dies because of missed airway visualization or failed intubation, but due to failed ventilation, which remains without doubt the gold standard of any patient safety goal and airway management technique.
\end{abstract}

Key words: Laryngoscopy; Video Recording; Intubation, Intratracheal; Education, Medical

Airway management remains one of the main tasks for anesthesiologists and failure in airway control remains one of the most important sources of perioperative morbidity and mortality in anesthesia ${ }^{1}$. For this reason, many different strategies, devices and techniques have been developed in the last years to face this reality and to improve periprocedural safety.

Ventilation and oxygenation remain the main targets in terms of patient safety, whereas laryngoscopy is probably the key point, if not even the starting point of any airway management strategy ${ }^{2}$. We know that many factors, including patient condition and anatomy, operator experience, and device availability and setting $^{3}$ may make laryngoscopy very difficult if not impossible, underlining how the conventional $\mathrm{Ma}-$ cintosh approach ('standard laryngoscopy' or 'direct

Correspondence to: Massimiliano Sorbello, MD, Via Genova 80, 95127 Catania, Italy

E-mail: maxsorbello@gmail.com

Received March 3, 2015, accepted: September 13, 2015 laryngoscopy'), which remains the most popular approach for airway visualization, might show important limitations.

\section{Everything in Line}

Several years ago, Cooper wrote an amazing editorial on the future of laryngoscopy ${ }^{4}$, reminding us that what makes man different from other species is disalignment of airway and esophagus, which on the one hand allows us social behavior during meals, but on the other hand generates a real challenge for airway management.

Basic for conventional laryngoscopy, and consequently for intubation, is achieving the so called 'line of sight', between the physician's eye and the larynx. For this purpose, any anesthesiologist, even if still inexperienced, knows that intubation maneuver starts with patient's head positioning so to achieve alignment between the operator's eye and oral, pharyngeal 
and laryngeal axes, which are naturally not on the same line ${ }^{5}$.

In most cases, some although basic skill with laryngoscope, correct patient position (the so called sniffing morning air position or modified Jackson position) and proper compromise between the force and leverage will result in laryngeal exposure. This is a typical moment when the anesthesiologist will stop holding his breath, whereas the patient is still apneic. At this point, intubation is generally almost natural consequence and airway is controlled.

Unfortunately, in a certain percentage of cases, ranging from $3 \%$ to $13 \%$ according to the literature ${ }^{2}$ regarding operation room, laryngoscopy is not so obvious, and both the patient's and the anesthesiologist's apnea could be prolonged.

The main reason for standard laryngoscopy failure is difficulty or impossibility to obtain the line of sight, resulting in impaired laryngeal exposure, defined as classic $^{6}$ or extended ${ }^{7}$ Cormack-Lehane classification; here we are facing the most intuitive definition of difficult airway management.

Taking closer look at the problem made us aware that many factors can result in difficult laryngoscopy and, very similarly, in failed intubation, e.g., reduced mouth opening (limiting the fulcrum of the leverage provided by the blade and reducing the oral axis angle) and going on with a large tongue, hard and poorly movable submandibular compartment or neck joints, stiff prelaryngeal tissue, reduced critical distance (such as thyromental or sternomental distance), and some more specific points such as neck circumference or history of sleep apnea ${ }^{2,3}$.

\section{No More Line, Time to Curve!}

Starting from consideration that a certain number of laryngoscopies remain difficult, great efforts have been invested in research by the scientific community and respective activities by the manufacturers, so that after more than 50 years of glorious activity, the approach to laryngoscopy has changed dramatically. It is the era of video laryngoscopes and, generally, the time for an approach which was not aimed at pursuing the line of sight anymore, but rather to follow natural curves of the anatomy, surrounding physiologic obstacles and bringing the physician's eye close to the larynx. From the line of sight, we have moved to "look around the corner"

Based on this concept, these new devices do not require any alignment of airway axes and operator's eye, as the laryngoscope blade is designed and built according to normal airway anatomy and curvature, and the observing point is moved far from the eye and transferred on the instrument tip with different optical solutions.

This approach has represented an important alternative to standard laryngoscopy to face difficult laryngoscopy situations, and there is increasing evidence that video laryngoscopy improves glottic exposure per se and in comparison with standard laryngoscopy; on the other hand, as we will see, it has opened new chapters and definitions of difficulty.

\section{Seeing is Believing}

A side effect, could we call it this way, of video laryngoscopy diffusion, was the increasing need of the anesthesiologist population to see better and in higher definition what they were used to see before video laryngoscopy. Thanks to technological evolution, miniaturization and marketing needs, many devices started to incorporate optical solutions: many video laryngoscopes came out in different models and concepts ${ }^{9,10}$, so that today we have unchanneled devices, which do need stylet for better performance, and channeled devices, which come with a side channel aimed to railroad the tube toward the larynx. Finally, there are new hybrid devices which put together features of channeled and unchanneled ones, and interchangeable blades in order to maintain both standard Macintosh (but video-enhanced) approach and video laryngoscopic approach ${ }^{11}$.

Apart from video laryngoscopes, video optical stylets try to put together conventional and classic stylet principle (stiffening and railroading endotracheal tube) with adoption of video systems to obtain view of the instrument tip position ${ }^{12}$. A camera has also been inserted in modified endotracheal tubes ${ }^{13}$ or in modified extraglottic devices (such as C-Trach ${ }^{\circledR}$, Teleflex Medical, Dublin, Ireland; Totaltrack, Medcomflow, Spain) ${ }^{14}$, so that these devices start to appear on the operating room carts and in literature reviews ${ }^{15}$. Similarly, fiberoptic approach, which used to be considered as an elitist technique, started to be ever more used 
and available, thanks also to higher interface opportunity between the instruments and availability of single use devices ${ }^{16}$.

We have officially entered the era of airway visualization and of technologic airway management, with powerful, portable and high performance instruments to solve almost any difficult airway situation. But, is it gold all that glitters?

\section{Seeing is Not Surviving}

Almost all studies of video laryngoscopes and video-aided intubation show clear advantage in terms of performance for these devices, at least if the endpoint is laryngeal visualization. Whatever the device, they provide (in good hands) almost always CL grade I or II of the larynx, view is often achieved easily and fast, and some differences occur only when we start considering intubation.

When approaching conventional laryngoscopy, the main difficulty is in achieving the line of sight; once we have good view of the larynx, intubation is generally easy. This is particularly true if we consider that good laryngoscopy "removes" any obstacle between the eye and the larynx and that tube maneuvering, simple or stylet/bougie supported, is always linear and with direct coordination between the physician's eye and hand.

Video laryngoscopy has shifted difficulty to intubation, rather than visualization, and it is relatively obvious. As no structures are dislodged, what is difficult is addressing the tube towards the larynx and negotiating its passage through the vocal cords. Not a case, unchanneled devices require a stylet, almost mandatorily, and channeled devices rely upon channel to address the tube, while paying due attention to increased thickness and reduced maneuver space.

Not only we should also consider the point for costs, as, to date, no device is cheaper than Macintosh, and we should ask ourselves if it could really be worth effort to use lot of resources to handle situations that are not so common and which could be handled with alternative devices such as introducers ${ }^{17}$.

Video laryngoscopes have been extensively researched and many papers have been produced; the point is that many studies were performed on manikins, or in conditions of simulated difficulty. If looking at pediatric video laryngoscope clinical use, the lack of wide and well performed human studies is even clearer.

Some devices showed peculiar limitations, such as influence of external light (thus limiting their use out of hospital emergency room); influence of mouth opening (so that new parameters should be defined for video laryngoscopic intubation), and the so called point of "blind spots" ${ }^{18}$ requiring particular care during maneuvers, especially in crowded mouth so to avoid "new" complications such as palatal or tonsillar perforations.

The last but not the least, none of these devices allows patient ventilation/oxygenation. Thus, their use should be limited to patients in which no difficult ventilation is expected, in particular taking into account mouth opening and interincisor distance, as these devices compared with conventional laryngoscopy require larger distances for comfortable and successful introduction. Then, it should be underlined that difficulty shift which has been described for video laryngoscopes has other important implications: while view is always better with video laryngoscopes (and even in this case we could argue that most of papers are based on classic Cormack-Lehane scale, which was designed for direct laryngoscopy, while different scales such as Percentage of Glottic Opening (POGO) scale should be adopted ${ }^{19}$ ), many papers clearly show that time to intubation is generally longer with video laryngoscopes, and, if endpoint is taken on periprocedural saturation, lower values are observed in video laryngoscopy groups ${ }^{20,21}$.

Finally, we should consider the problem of learning curve, skill development and maintenance; video devices offer an incredible opportunity of didactic potential, allowing difficulty sharing and targeted help and teaching. On the other hand, it has been recently shown that learning curve for video laryngoscopes is not so obvious as it was in the past ${ }^{22}$, and it could take more than 75 attempts $^{23}$ to have perfect performance of video laryngoscopy as compared with 47 described in a classic paper by Mulcaster et al. ${ }^{24}$ for Macintosh laryngoscope.

So, it could not always be so easy, and it could be a greater risk to abandon the classic Macintosh approach which, until contrary proof, has actually the most widespread usage and the best cost/benefit ratio. 


\section{Key Role of Oxygenation versus Visualization}

Laryngoscopy remains probably the most important phase of any "standard" airway management strategy, but recent papers and guidelines ${ }^{2}$ focus on the importance of ventilation and oxygenation rather than intubation itself, whereas its role in airway control and isolation remains pivotal.

If looking at intubation, contribution of new technologies and video assisted intubation is outstanding, with high successes and safest approach to airway management, from intubation to tube exchange procedures, applications in intensive care unit and emergency re-intubation, including specific airway maneuvers using a combination of devices which, in expert hands, can represent the safest and best performing solution for specific airway problems ${ }^{25}$. Like any new technology, they will require time, learning curve, clinical studies to prove benefit and show limitations and side effects, and time to convince the most reluctant and traditionalist physicians.

In any case, airway visualization, although fundamental, is not the most important moment for airway management. No patient dies for failed visualization of vocal cords, and no patient dies because of missed intubation. Probably, patients do die for excessive attempts at intubation, and new frontiers are now appearing in the dynamics of errors in anesthesia, starting from the so called fixation error, for which repeated (and unchanged) laryngoscopic attempts are paradigmatic.

Patient dies because of failed or missed ventilation and oxygenation, and both these maneuvers could be performed, in certain sense, blindly.

Recent data from NAP4 ${ }^{26}$ and old data from Closed Claims Analysis ${ }^{1}$ show that a large number of errors and deaths could be avoided working on the strategy rather than devices. Development of procedural pathway is primary and more important than single device we will use in the procedure.

Obviously, improved airway visualization will raise not only safety, but also quality standards. Some centers do regularly use video laryngoscopes and do build their procedures based on these device performances ${ }^{27}$, but this behavior is not reproducible everywhere.

For sure, video devices do have a role in difficult airway management strategies, and they are entering many difficult airway management guidelines with a precise role and position ${ }^{28}$, but it is still too early to think they will replace Macintosh laryngoscope ${ }^{29}$.

And above all, in the era of enhanced visualization, relying completely upon these new high performance video devices could be an error of blindness because whatever the device, we should remind the Chinese proverb: eyes see what mind knows; and mind should know laryngoscopy but it must see oxygenation first.

\section{References}

1. Peterson GN, Domino KB, Caplan RA, Posner KL, Lee LA, Cheney FW. Management of the difficult airway: a closed claims analysis. Anesthesiology. 2005;103:33-9.

2. Frova G, Sorbello M. Algorithms for difficult airway management: a review. Minerva Anestesiol. 2009;75(4):201-9.

3. Frova G, Guarino A, Petrini F, Merli G; Siaarti Difficult Airways Study Group. Recommendations for airway control and difficult airway management. Minerva Anestesiol. 2005;71:617-57.

4. Cooper RM. Laryngoscopy - its past and future. Can J Anaesth. 2004;51:R1-R5.

5. Adnet F, Baillard C, Borron SW, Denantes C, Lefebvre L, Galinski M, et al. Randomized study comparing the 'sniffing. position' with simple head extension for laryngoscopic view in elective surgery patients. Anesthesiology. 2001;95:836-41.

6. Cormack RS, Lehane J. Difficult tracheal intubation in obstetrics. Anaesthesia. 1984;39:1105-11.

7. Yentis SM, Lee DJ. Evaluation of an improved scoring system for the grading of direct laryngoscopy. Anaesthesia. 1998;53:1041-4.

8. Cooper RM, Pacey JA, Bishop MJ, McCluskey SA. Early clinical experience with a new video laryngoscope (GlideScope) in 728 patients. Can J Anaesth. 2005;52:191-8.

9. Savoldelli GL, Schiffer E, Abegg C, Baeriswyl V, Clergue F, Waeber JL. Comparison of the GlideScope, the McGrath, the Airtraq and the Macintosh laryngoscopes in simulated difficult airways. Anaesthesia. 2008;63:1358-64. doi: 10.1111/j.1365-2044.2008.05653.x.

10. Malik MA, O'Donoghue C, Carney J, Maharaj CH, Harte BH, Laffey JG. Comparison of the GlideScope, the Pentax AWS, and the TruView EVO2 with the Macintosh laryngoscope in experienced anaesthetists: a manikin study. $\mathrm{Br} \mathrm{J}$ Anaesth. 2009;102(1):128-34. doi: 10.1093/bja/aen342.

11. Aziz M, Bambrink A. The Storz C-MAC video laryngoscope: description of a new device, case report, and brief case series. J Clin Anesth. 2011;23:149-52. doi: 10.1016/j. jclinane.2010.01.006.

12. Ezri T, Szmuk P. Recent trends in tracheal intubation: emphasis on the difficult airway. Curr Opin Anaesthesiol. 2004;17:487-90. 
13. Gaitini LA, Yanovski B, Mustafa S, Hagberg CA, Charco Mora P, Vaida SJ. A feasibility study using the VivaSight Single LumenTM to intubate the trachea through the Fastrach Laryngeal Mask Airway: a preliminary report of 50 cases. Anesth Analg. 2013;116:604-8. doi: 10.1213/ ANE.0b013e31827b278f.

14. Hernandez MR, Klock AJr, Ovassapian A. Evolution of the extraglottic airway: are view of its history, applications, and practical tips for success. Anesth Analg. 2012;114:349-68. doi: 10.1213/ANE.0b013e31823b6748.

15. Mihai R, Blair E, Kay H, Cook TM. A quantitative review and meta-analysis of performance of non-standard laryngoscopes and rigid fiberoptic intubation aids. Anaesthesia. 2008;63:745-60. doi: 10.1111/j.1365-2044.2008.05489.x.

16. Vijayakumar M, Clarke A, Wilkes AR, Goodwin N, Hodzovic I. Comparison of the manoeuvrability and ease of use of the AmbuaScope and Olympus re-usable fibrescope in a manikin. Anaesthesia. 2011;66:689-93. doi: 10.1111/j.13652044.2011.06761.x.

17. Sorbello M, Frova G. Frova introducer: neither a stylet nor simply an introducer. Anaesthesia. 2008;63:1010-1. doi: 10.1111/j.1365-2044.2008.05661_1.x.

18. Magboul MAM, Shaw J. The video laryngoscopes, blind spots and retromolar trigonum injury by the GlideRite ${ }^{\circledR}$ rigid stylet. Anesth Essays Res. 2010;4(2):112-4. doi: 10.4103/02591162.73519.

19. Ochroch EA, Hollander JE, Kush S, Shofer FS, Levitan RM. Assessment of laryngeal view: percentage of glottic opening score vs Cormack and Lehane grading. Can J Anesth. 1999;46:987-90.

20. Su YC, Chen CC, Lee YK, LeeJY, Lin KJ. Comparison of video laryngoscopes with direct laryngoscopy for tracheal intubation: a meta-analysis of randomized trials. Eur J Anaesthesiol. 2011;28:788-95. doi: 10.1097/EJA.0b013e32834a34f3.

21. Griesdale DEG, Liu D, Mckinney J, Choi PT. Glidescope ${ }^{\circledR}$ video-laryngoscopy versus direct laryngoscopy for endotra- cheal intubation: a systematic review and meta-analysis. Can J Anaesth. 2012;59(1):41-5. doi: 10.1007/s12630-011-9620-5.

22. Maharaj CH, Ni Chonghaile M, Higgins BD, Harte BH, Laffey JG. Tracheal intubation by inexperienced medical residents using the Airtraq and Macintosh laryngoscopes - a manikin study. Am J Emerg Med. 2006;24:769-74.

23. Cortellazzi P, Caldiroli D, Byrne A, Sommariva A, Orena EF, Tramacere I. Defining and developing expertise in tracheal intubation using a GlideScope $\left({ }^{\circledR}\right)$ for anaesthetists with expertise in Macintosh direct laryngoscopy: an in vivo longitudinal study. Anaesthesia. 2015;70(3):290-5. doi: 10.1111/ anae. 12878.

24. Mulcaster JT, Mills J, Hung OR, Macquarrie K, Law JA, Pytka S, et al. Laryngoscopic intubation: learning and performance. Anesthesiology. 2003;98(1):23-7.

25. Sharma D, Kim LJ, Ghodke B. Successful airway management with combined use of GlideScope video laryngoscope and fiberoptic bronchoscope in a patient with Cowden syndrome. Anesthesiology. 2010 Jul;113(1):253-5. doi: 10.1097/ ALN.0b013e3181dfd334.

26. Cook TM, Woodall N, Frerk C, on behalf of the Fourth National Audit Project. Major complications of airway management in the UK: results of the Fourth National Audit Project of the Royal College of Anaesthetists and the Difficult Airway Society. Part 1: Anaesthesia. Br J Anaesth. 2011;106(5):617-31. doi: 10.1093/bja/aer058.

27. Caldiroli D, Cortellazzi P. A new difficult airway management algorithm based upon the El Ganzourri Risk Index and GlideScope video laryngoscope. A new look for intubation? Minerva Anestesiol. 2011;77:1011-7.

28. Frova G. Do video laryngoscopes have a new role in the SIAARTI difficult airway management algorithm? Minerva Anestesiol. 2010;76:637-40.

29. Merli G, Guarino A, Petrini F, Sorbello M, Frova G. Should we really consider to lay down the Macintosh laryngoscope? Minerva Anestesiol. 2012;78:1078-9. 


\section{Sažetak}

\section{VIZUALIZACIJA DIŠNOG PUTA: OČI VIDE ONO ŠTO MOZAK ZNA}

\section{Sorbello, G. Frova i I. Zdravković}

Održavanje dišnog puta je osnovna anesteziološka vještina koja ponekad predstavlja u pravom smislu dramatičan scenarij za bolesnika i liječnika. Laringoskopija, sa svim svojim ograničenjima i neuspjesima, predstavlja zlatni standard vizualizacije dišnog puta već više od 60 godina. Nove tehnologije, zahvaljujući videolaringoskopiji i video asistiranim tehnikamaodržavanja dišnog puta, omogućile su pomicanje očiju liječnika unutar dišnog puta bolesnika. Bez sumnje, ušli smo u novu eru visoke rezolucije vizualizacije dišnog puta i različitog pristupa instrumentalizaciji dišnog puta. Međutim, svaka nova tehnologija zahtijeva vrijeme da bi se testirala i smatrala pouzdanom. Zapreke i ograničenja mogu se iznjedriti nakon pažljive i dugotrajne analize, stoga vjerojatno još nije vrijeme da se promovira video asistirani pristup kao novi zlatni standard u vizualizaciji dišnog puta, iako on definitivno predstavlja novu budućnost. U svakom slučaju, koji kod bio pristup vizualizaciji, nijedan bolesnik ne umire zbog propuštene vizualizacije ili neuspjele intubacije, već umire zbog neuspješne ventilacije koja ostaje bez sumnje zlatni standard bilo kojeg cilja za sigurnost bolesnika i tehnike zbrinjavanja dišnog puta.

Ključne riječi: Laringoskopija; Video snimanje; Intubacija, intratrahealna; Edukacija, medicinska; Respiracija, umjetna; Education, medical 